\title{
Detection of HPV infection in head and neck cancers: Promise and pitfalls in the last ten years: A meta-analysis
}

\author{
CAROLIN GÖTZ, CLARA BISCHOF, KLAUS-DIETRICH WOLFF and ANDREAS KOLK \\ Department of Oral and Maxillofacial Surgery, Technical University of Munich, \\ Klinikum Rechts der Isar, D-81675 Munich, Germany
}

Received October 27, 2017; Accepted August 9, 2018

DOI: $10.3892 / \mathrm{mco} .2018 .1749$

\begin{abstract}
The current controversial discussion on the diseasespecific survival of patients with human papillomavirus (HPV)-positive (+) and -negative (-) squamous cell carcinoma (SCC) of the head neck region was the motivation for the present meta-analysis. Different detection methods for HPV are available, though these often lack sensitivity. As a consequence, there may be false interpretation of HPV positivity. A bias concerning HPV status and therefore also survival rates is serving a non-durable relevance in the discussion of tailored therapies. A literature search was performed via the online database PubMed/NCBI, and data extraction and statistical analysis were conducted. A total of 139 studies published between 2004 and 2014 were evaluated in the present meta-analysis. The HPV detection methods, patient characteristics, tumor localizations and stages, as well as (neo-) adjuvant therapies and survival times were analyzed. The average incidence rates of $\mathrm{HPV}^{+}$patients with oropharyngeal tumors were higher than those of patients with cancers of other regions of the head and neck. Upon evaluating the results of different detection methods no significant differences were identified. We have compared the HPV incidence rates of each detection method, when studies have used more than one. Regarding overall survival, the pooled adjusted hazard ratio (HR) for oropharyngeal SCC was 0.31 [95\% confidence interval $(\mathrm{CI})=0.27-0.36]$. Unfortunately, only 3 equivalent studies were available on nonoropharyngeal tumors, for which the pooled adjusted HR was $1(95 \%$ $\mathrm{CI}=0.73-1.36)$. Overall, the evaluation demonstrated that the survival rates reported in numerous studies were not evaluated multifactorially and important confounders were excluded from the statistics. The HPV detection methods used were often not sufficient in representing HPV positivity. In addition,
\end{abstract}

Correspondence to: Dr Carolin Götz, Department of Oral and Maxillofacial Surgery, Technical University of Munich, Klinikum Rechts der Isar, Ismaninger Street 22, D-81675 Munich, Germany E-mail:cg.goetz@tum.de

Key words: human papillomavirus, oropharyngeal squamous cell carcinoma, detection methods, survival oropharyngeal and oral SCCs were assessed together in the localization. The widely differing number of $\mathrm{HPV}^{+}$patients in each of the various studies may be explained by insufficient detection methods and by a lack of localization distinction. The considerations of a tailored therapy according to HPV status should be rejected based on the present information. The previously published studies should be read critically and do not represent a basis for therapeutic decisions.

\section{Introduction}

Head and neck cancer (HNC) is reportedly the sixth most common cancer diagnosed worldwide; in 2008, 633,000 new cases were diagnosed, and $\sim 355,000$ cases resulted in mortality (1). HNC encompasses all malignant tumors of the upper aerodigestive tract, which begins at the vermilion border of the lips and extends to the beginning of the esophagus. Approximately $90 \%$ of malignant neoplasms of the head and neck are squamous cell carcinomas (SCCs), while only just $>5 \%$ are adenocarcinomas (2). The incidence rate varies according to geographic region and associated risk factors of differing severity. In recent decades, a declining incidence rate, particularly for the cancers of the oral cavity, hypopharynx and larynx, has been observed as an effect of reduced tobacco consumption in industrialized countries. However, in contrast, there has been a rapid increase in the incidence rate of oropharyngeal cancers, particularly of those of the tonsils and base of the tongue, which have been associated with human papilloma virus (HPV) $(3,4)$. In 1983, HPV was first reported in association with head and neck SCC (HNSCC) (5). The International Agency for Research on Cancer officially recognized HPV-16 infection as a risk factor for oropharyngeal SCC (OPSCC) in 2007 (6). In recent decades, the number of oropharyngeal cancers caused by HPV has risen sharply: From 1988 to 2004, it increased in the US by $\leq 225 \%$ (7). But not only in North America, also in Europe this observation was found $(8,9)$. Of the 100 cancers of the pharynx, 40 are assumed to be associated with HPV (2). HPV-associated HNSCCs occur in different populations from those with cancers induced by noxious agents, and different pathogenic processes underlie their oncogenesis. In the literature, a notable discordance exists among individual studies of HPV-associated HNSCC. Estimates of the incidence rate of HPV-associated tumors also differ greatly. Furthermore, the majority of studies conclude 
that patients with HPV-associated HNSCC have a survival advantage. An important question regarding the selection of a therapeutic approach in the future is whether treatment that is less intense will be sufficient for HPV-associated tumors.

The objectives of the present study were to improve current understanding concerning: The incidence rate of HPV-associated tumors; the most reliable detection methods; and the survival probability of $\mathrm{HPV}^{+}$patients.

\section{Materials and methods}

Search strategy. The meta-analysis was conducted according to the guidelines of the Cochrane Collaboration and the Preferred Reporting Items for Systematic Reviews and Meta-Analyses statement $(10,11)$. For an online literature search, the PubMed database was used. To identify the primary studies, the following terms were combined: 'HPV' and 'HNSCC', 'oral cavity', 'OPSCC', 'oropharyngeal' or 'tonsil' and 'overall survival', 'disease-specific survival' or 'treatment modalities'.

Study eligibility and data extraction. The following conditions were defined for the incorporation of studies into the meta-analysis: The object of interest had to be a patient diagnosed with HNSCC; each study had to include at least 50 patients (two exceptions - there have been $\geq 50$ patients, but only 42 respectively 49 were available for HPV testing. These two studies were included because they seemed to be very useful, due to the fact both evaluated many parameters and also considered the kind of treatment.); HPV detection had to be conducted and explained; and the survival rates had to be described and separated into $\mathrm{HPV}^{+} / \mathrm{HPV}^{-}$groups. Reviews and previous meta-analyses were not eligible. The publication was not included if it was more than 10 years old (two exceptions) and if it was not written in German or English. Additionally, the publication had to be available as full text. The selected studies were analyzed with respect to the following parameters: Number of patients, HPV detection method and the number of $\mathrm{HPV}^{+} / \mathrm{HPV}^{-}$test results, HPV subtypes, tumor localization, treatment, mean age of $\mathrm{HPV}^{+} / \mathrm{HPV}^{-}$patients at the time of diagnosis, alcohol consumption of $\mathrm{HPV}^{+} / \mathrm{HPV}^{-}$patients, tobacco use of $\mathrm{HPV}^{+} / \mathrm{HPV}^{-}$patients, sex of $\mathrm{HPV}^{+} / \mathrm{HPV}^{-}$patients, tumor, node and metastasis (TNM) stage, country and outcome. The extracted data were collected in an Excel spreadsheet.

Statistical analysis. In the statistical evaluation, the respective minima, maxima, means and medians were determined for all extracted data sets of the above-mentioned criteria. The statistical analysis of the data to compare the detection methods and the data on the supposed survival advantage was carried out with the support of the staff of the Institute of Medical Statistics and Epidemiology of the Technical University of Munich.

For the comparison of the different detection methods the 'Random-Effect' model was used and the Risk Difference (RD) with the $95 \%$ CI was calculated. After the heterogeneity test, also for the statistical evaluation of the supposed survival advantage, the 'Random-Effect' model was used. And by using the published hazard ratios (HR) and their $95 \%$ confidence interval (CI) the pooled HR for overall survival (OS) was calculated. For data collection, statistical analysis

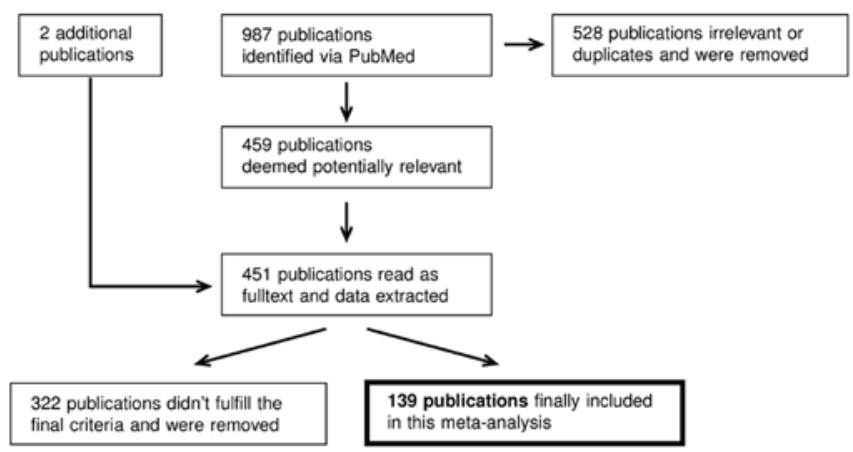

Figure 1. Schematic of the methodology employed for the literature research (Bischof $\mathrm{C}$ : PhD Thesis, in prep). Workflow of the data acquisition via literature research: Identification by keyword queries in PubMed, followed by removal of duplicates, inclusion of two additional older but well cited papers, then data extraction and the final dataset.

and the preparation of tables and charts, Microsoft Excel 2011 (Microsoft Corporation, Redmond, WA, USA) and R packages (cran.r-project.org/) were used.

\section{Results}

Literature search results. The literature search via PubMed yielded a total of 987 hits. The flow diagram in Fig. 1 illustrates how a final of 139 publications were selected. All abstracts were read to identify useful publications, and duplicates were rejected. In total, 459 publications, which were perceived as helpful, were read as full text. Among the sources of these publications, two further studies ( $>10$ years) were identified to be useful and included in the present meta-analysis. The relevant data were extracted and transferred to an Excel spreadsheet. In 139 publications out of the 461 studies, including a total of 21,774 patients, fulfilled the final criteria. Of these studies, 80 were concerned solely with OPSCC (7,12-90), 13 with oral SCC (OSCC) (91-103) and 31 with both OPSCC and OSCC (104-134); 15 studies provided results on HNSCC in general (135-149).

HPV prevalence. The average percentage of patients tested as $\mathrm{HPV}^{+}$estimated from all included studies in the meta-analysis was $42.62 \%$ [95\% CI=0.39-0.46]. The mean incidence rate of the 80 OPSCC studies (12,662 patients, 6,383 $\left.\mathrm{HPV}^{+}\right)$was $49.85 \%$ (95\% CI=0.45-0.54). By contrast, for the 13 studies on OSCC, the mean incidence rate was $27.39 \%(95 \%$ $\mathrm{CI}=0.18-0.36)$. In a further analysis, anatomic regions were divided more specifically. As the anatomical localization of the oropharynx is of special interest according to HPV positivity, this region was further divided into: Base of the tongue, tonsils and neither of these two locations [listed as other oropharyngeal SCC (OOPSCC) in Table I]. The average incidence rate of $\mathrm{HPV}^{+}$patients with OPSCC was $50.47 \%(95 \% \mathrm{CI}=0.47-0.54)$. Notably, cancers of the base of the tongue, with an average incidence of $\mathrm{HPV}^{+}$patients of $48.61 \%$ (95\% CI=0.42-0.56), and of the tonsils, with an average incidence of $\mathrm{HPV}^{+}$patients of $55.32 \%$ (95\% CI=0.50-0.61), exhibited a relatively high association with HPV infection in particular. By contrast, oropharyngeal cancer, classified as being outside of these two regions, tested as $\mathrm{HPV}^{+}$to a much lower extent, with an average 
Table I. Overview of the incidence rates.

\begin{tabular}{lcccccc}
\hline Variables & $\begin{array}{c}\text { No. } \\
\text { of studies }\end{array}$ & $\begin{array}{c}\text { No. } \\
\text { of patients }\end{array}$ & $\begin{array}{c}\text { Patients } \\
\mathrm{HPV}^{+}\end{array}$ & $\begin{array}{c}\text { Average } \\
\mathrm{HPV}^{+}(\%)\end{array}$ & $\begin{array}{c}\text { Minimum } \\
\mathrm{HPV}^{+}(\%)\end{array}$ & $\begin{array}{c}\text { Maximum } \\
\mathrm{HPV}^{+}(\%)\end{array}$ \\
\hline All studies & 139 & 21,774 & 9,016 & 42.62 & 5.68 & 89.20 \\
OSCC studies & 13 & 2,044 & 495 & 27.39 & 5.68 & 64.00 \\
OPSCC studies & 80 & 12,662 & 6,383 & 49.85 & 11.54 & 89.20 \\
HNSCC & 20 & 3,433 & 1,049 & 32.93 & 11.56 & 68.63 \\
In HNSCC studies & & & & & 25.09 \\
OSCC & 40 & 3,550 & 737 & 24.14 & 0.00 & 75.68 \\
OPSCC & 110 & 14,230 & 7,178 & 50.47 & 3.23 & 95.00 \\
OOPSCC & 33 & 809 & 205 & 26.39 & 0.00 & 52.94 \\
Base of tongue & 34 & 1,501 & 760 & 48.61 & 1.85 & 82.26 \\
Tonsils & 55 & 4,316 & 2,272 & 55.32 & 4.29 & 95.00 \\
Larynx & 24 & 1,402 & 232 & 20.61 & 0.00 & 50.38 \\
Hypopharynx & 22 & 629 & 132 & 22.18 & 0.00 & 58.33 \\
\hline
\end{tabular}

OPSCC, oropharyngeal squamous cell carcinoma; OSCC, oral squamous cell carcinoma; HNSCC, head and neck squamous cell carcinoma; OOPSCC, other oropharyngeal squamous cell carcinoma.

incidence of HPV positivity of $26.39 \%(95 \% \mathrm{CI}=0.22-0.31)$. The average incidence rates of $\mathrm{HPV}^{+}$patients with tumors of other head and neck regions excluding OPSCCs were generally below those for oropharyngeal tumors: For OSCC, $24.14 \%$ (95\% CI=0.18-0.30), for laryngeal cancer, $20.61 \%$ (95\% CI=0.140.27) and for hypopharyngeal cancer, $22.18 \%$ (95\% CI=0.14-0.31). For HNSCC, the average incidence of HPV positivity was $32.93 \%$ (95\% CI=0.27-0.39; Table I).

HPV detection. Of the studies, 95 involved polymerase chain reaction (PCR), 80 used p16 immunohistochemistry (IHC) and 30 studies employed in situ hybridization (ISH). A total of 79 studies determined HPV status with one detection method, while 60 studies used two, or all three, of the above methods. Evaluation of the different results regarding the incidence rates, if studies have used multiple detection methods, revealed no significant difference between PCR and IHC, ISH and PCR, and IHC and ISH (Fig. 2A-C).

HPV subtypes. A total of 80 studies (11,455 patients) provided information on the HPV subtypes. Among the 4,086 patients that tested $\mathrm{HPV}^{+}$, the two high-risk types HPV16 and 18 were the most frequently detected subtypes. In OPSCC (44 studies), HPV16 was detected on average in $90.55 \%$ (95\% CI=0.87-0.94) of cases, and HPV18 was responsible for the infection on average in $8.10 \%(95 \% \mathrm{CI}=0.05-0.11)$ of cases. Among the HPV-associated OSCC cases (10 studies), HPV16 and 18 were detected on average in $69.66 \%(95 \% \mathrm{CI}=0.52-0.87)$ and $26 \%$ (95\% CI=0.19-0.33) of the cases, respectively.

Associations with HPV profile. Data regarding other risk factors (age, TNM status, alcohol and tobacco consumption, sex) and differences between $\mathrm{HPV}^{+}{ }^{-}$cases are summarized in Fig. 3. The most interesting finding was, that $\mathrm{HPV}^{+}$patients with OPSCC were often described to be younger than HPV patients, also the mean age was lower for $\mathrm{HPV}^{+}$patients with OPSCC (56.5 vs. 60.8 years). But this fact could not be observed for $\mathrm{HPV}^{+}$- patients with OSCC. Distribution of the studies according to the various countries and the mean incidence rates for OPSCC according to country are also given in Fig. 3.

HPV and patient survival. In the 135 studies providing information on patient survival, 94 reported an improved outcome for patients who tested $\mathrm{HPV}^{+}, 5$ documented a poorer survival rate, 25 could not detect any significant difference, and 11 reported a higher probability of survival only with $\mathrm{HPV}^{+}$oropharyngeal tumors. Out of the 135 studies, 77 focused on oropharyngeal tumors with information on survival; 67 of these reported of an improved outcome in $\mathrm{HPV}^{+}$patients, and 10 could not detect a significant difference. Of the 12 studies on OSCC with data on survival rates, 3 reported an improved outcome in $\mathrm{HPV}^{+}$patients, 3 a poorer outcome, and 6 could not detect a significant difference. The data on the probability of survival were described in various formats, with the largest amount of comparable data being available for overall survival. The pooled adjusted hazard ratio (HR) for OPSCC was 0.31 (95\% CI=0.27-0.36). Unfortunately, only 3 equivalent studies were available for nonoropharyngeal tumors, for which the pooled adjusted HR was 1 (95\% CI=0.73-1.36, Fig. 4A and B).

\section{Discussion}

In the literature, the way in which prevalence rates of HPV-associated HNSCC are described varies greatly, with the main variant factors being insufficient description and fractionation of anatomical localizations, different risk factors (attributable to the time-point and the place of study), and non-uniform detection methods. In the present meta-analysis, the average incidence rate of HPV-associated 

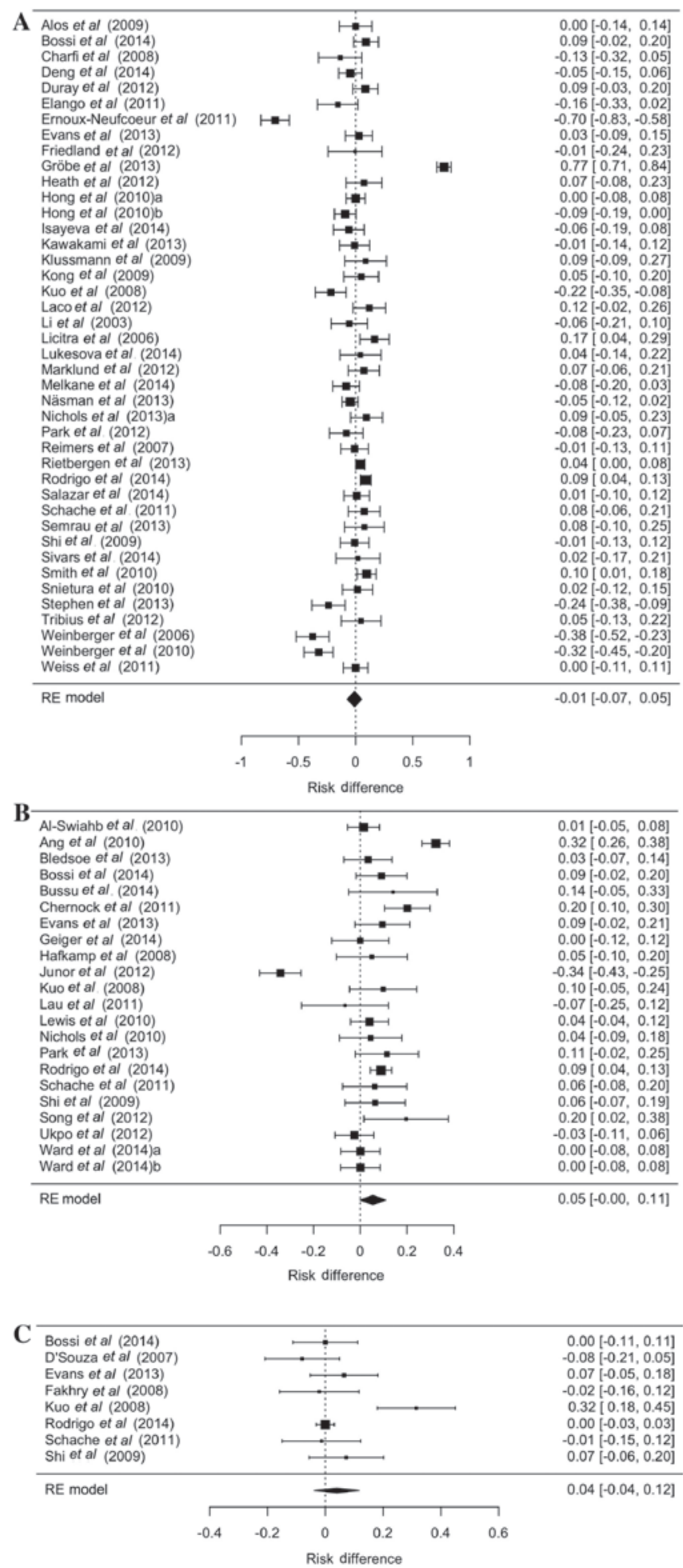

Figure 2. Risk differences due to HPV detection method in studies which used several HPV detection methods (Bischof C: PhD Thesis, in prep). (A) PCR and IHC; (B) ISH and PCR; and (C) IHC and ISH. By pooling the proportion of patients tested HPV-positive by the different methods the present study performed comparisons between them. HPV, human papillomavirus; PCR, polymerase chain reaction; IHC, immunohistochemistry; ISH, in situ hybridization.

HNSCC was $42.62 \%$. In a similar meta-analysis of 60 studies (5,046 patients), the average incidence rate was $25.9 \%$ (95\% CI=0.25-0.27) (150). Another meta-analysis of 34 studies (5,681 patients) reported that $21.95 \%$ (95\% CI=0.21-0.23) of
HNSCCs were associated with HPV (151). The significantly higher incidence rate in the present analysis may be attributable either to i) more than half of the included studies (80 studies, 12,662 patients) only investigating OPSCC, which is known to be more frequently associated with HPV (150); ii) studies older than 10 years not being included. Analysis of the $5 \%$ of studies with the highest/lowest incidence rates of HPV-associated HNSCC revealed notable similarities: In contrast to the studies with low incidence rates, most studies with high incidence rates were from North America and involved exclusively OPSCC $(15,28,31,46,49,54,79,94,97,100,112,120,136,140)$. The average prevalence rate in the 110 studies (14,230 patients) that provided data on tumors of the oropharynx was $50.47 \%$; in the two meta-analyses mentioned above, the average incidence rate of HPV-associated OPSCC was 35.6\% (95\% CI=0.33-0.39) (150) and $41 \%$ (95\% CI=0.38-0.44), respectively (151). Again, the different time periods over which the studies were conducted may be responsible for the observed differences. Many studies have reported a dramatic increase in the incidence of HPV-associated OPSCC in recent decades $(8,9)$. However, even among the HPV-associated OPSCC cases, a relatively high level of variation exists in incidence rate (minimum: $11.54 \%$, maximum: $89.20 \%)(28,49)$. Furthermore, analysis of the $5 \%$ of OPSCC studies with the highest/lowest incidence rates of HPV-association determined some similarities: All of the $5 \%$ of studies with the highest incidence rates were conducted in North America, whereas none of the studies with the lowest incidence rates was conducted in North America $(15,22,28,31,41,49,54,73)$. The studies with the low incidence rates of HPV-associated HNSCC mentioned the different geographic regions $(41,73)$, the higher prevalence of 'classic' risk factors and therefore a lower HPV prevalence $(22,41,73)$, and the data collection over many years $(28,73)$ as possible causes of the low incidence rates of HPV-associated HNSCC.

In the present analysis, OPSCCs were further divided into groups. Notably, a significantly higher HPV association for cancers of the tonsils and base of the tongue was observed, in contrast to cancers of other oropharyngeal regions. The average incidence rate of HPV-associated tumors (3,550 patients) of the 40 studies on OSCC was $24.14 \%$, and therefore was similar to that determined in the meta-analysis by Kreimer: $23.5 \%$ (95\% CI=0.22-0.25) (150). The current meta-analysis highlights the importance of a detailed description and distinction of the relevant anatomical localizations, since different HPV infection rates are obvious $(8,52,53)$. As another factor, the time of the study appears to influence the HPV incidence rate $(8,9)$; this may be explained by the significant decrease in smoking populations over the past decades (152). Due to the elimination of 'classic risk factors', including smoking and alcohol abuse, the number of cancers associated with other possible triggers increases. However, an increased HPV prevalence is also likely to serve a role; this may be attributable to changes in sexual practices and potential transmission via oral $\operatorname{sex}(24)$.

The lack of uniform standards for HPV detection makes it difficult to compare individual studies. Each detection method has its own advantages and disadvantages: In addition to sensitivity and specificity, the type of histological specimen, financial aspects, time available, and personal and equipment resources affect the choice of detection. Due to the various 


\begin{tabular}{|c|c|c|c|c|c|c|c|c|}
\hline \multicolumn{9}{|c|}{ HPV subtypes } \\
\hline & $\begin{array}{l}\text { Number } \\
\text { of studies }\end{array}$ & $\begin{array}{l}\text { Number } \\
\text { of patients }\end{array}$ & $\begin{array}{c}\text { Patients } \\
\text { HPV+ }\end{array}$ & $\begin{array}{l}\text { Patients } \\
\text { HPV-16 }\end{array}$ & $\begin{array}{l}\text { Patients } \\
\text { HPV-18 }\end{array}$ & $\begin{array}{l}\text { Average } \\
\% \text { HPV-16 }\end{array}$ & $\begin{array}{c}\text { Average } \\
\% \text { HPV-18 }\end{array}$ & \\
\hline All studies & 80 & 11455 & 4086 & 3583 & 169 & $87.32 \%$ & $11.65 \%$ & \\
\hline OPSCC & 44 & 6791 & 2707 & 2478 & 69 & $90.55 \%$ & $8.10 \%$ & \\
\hline oscc & 10 & 1533 & 384 & 229 & 71 & $69.66 \%$ & $26.00 \%$ & \\
\hline \multicolumn{9}{|l|}{ Age } \\
\hline & $\begin{array}{l}\text { Number } \\
\text { of studies }\end{array}$ & $\begin{array}{l}\text { Number } \\
\text { of patients }\end{array}$ & $\begin{array}{c}\mathrm{HPV}+ \\
\text { younger }\end{array}$ & $\begin{array}{l}\text { HPV+ } \\
\text { older }\end{array}$ & n.s. & & & \\
\hline All studies & 99 & 17977 & 43 & 4 & 52 & & & \\
\hline OPSCC & 60 & 11591 & 32 & 2 & 26 & & & \\
\hline \multirow[t]{2}{*}{ oscc } & 7 & 1008 & 0 & 0 & 7 & & & \\
\hline & $\begin{array}{l}\text { Number } \\
\text { of studies }\end{array}$ & $\begin{array}{l}\text { Number } \\
\text { of patients }\end{array}$ & $\begin{array}{c}\text { Mean age } \\
\text { HPV+ }\end{array}$ & $\begin{array}{c}\text { Mean age } \\
\text { HPV- }\end{array}$ & & & & \\
\hline All studies & 66 & 11633 & 57.4 & 61.1 & & & & \\
\hline OPSCC & 46 & 8261 & 56.5 & 60.8 & & & & \\
\hline oscc & 3 & 521 & 61.5 & 59.4 & & & & \\
\hline \multicolumn{9}{|l|}{ Tumor stage } \\
\hline & $\begin{array}{l}\text { Number } \\
\text { of studies }\end{array}$ & $\begin{array}{l}\text { Number } \\
\text { of patients }\end{array}$ & $\begin{array}{c}\text { Patients } \\
\text { HPV+ }\end{array}$ & $\begin{array}{l}\text { Patients } \\
\text { HPV- }\end{array}$ & $\begin{array}{c}\text { TNM I/II } \\
\text { HPV+ } \\
\text { (mean\%) }\end{array}$ & $\begin{array}{c}\text { TNM III/IV } \\
\text { HPV+ } \\
\text { (mean\%) }\end{array}$ & $\begin{array}{c}\text { TNM I/II } \\
\text { HPV- } \\
\text { (mean\%) }\end{array}$ & $\begin{array}{c}\text { TNM III/IV } \\
\text { HPV- } \\
\text { (mean\%) }\end{array}$ \\
\hline All studies & 73 & 11487 & 4939 & 6539 & $\begin{array}{c}749 / \\
18.95 \%\end{array}$ & $\begin{array}{l}4190 / \\
81.05 \%\end{array}$ & $\begin{array}{l}1808 / \\
23.18 \%\end{array}$ & $\begin{array}{l}4731 / \\
76.82 \%\end{array}$ \\
\hline OPSCC & 46 & 7258 & 3464 & 3794 & $\begin{array}{c}379 / \\
14.27 \%\end{array}$ & $\begin{array}{l}3085 / \\
85.73 \%\end{array}$ & $\begin{array}{c}974 / \\
19.73 \%\end{array}$ & $\begin{array}{l}2820 / \\
80.27 \%\end{array}$ \\
\hline oscc & 5 & 487 & 176 & 311 & $\begin{array}{c}98 / \\
54.44 \%\end{array}$ & $\begin{array}{c}78 / \\
45.56 \%\end{array}$ & $\begin{array}{c}139 / \\
42.52 \% \\
\end{array}$ & $\begin{array}{c}172 / \\
57.48 \%\end{array}$ \\
\hline \multicolumn{9}{|l|}{ Alcohol } \\
\hline & $\begin{array}{l}\text { Number } \\
\text { of studies }\end{array}$ & $\begin{array}{l}\text { Number } \\
\text { of patients }\end{array}$ & $\begin{array}{l}\text { Patients } \\
\text { HPV+ }\end{array}$ & $\begin{array}{l}\text { Patients } \\
\text { HPV- }\end{array}$ & $\begin{array}{l}\text { Alc } \\
\mathrm{HPV}+\end{array}$ & $\begin{array}{l}\text { Alc } \\
\text { HPV- }\end{array}$ & $\begin{array}{l}\text { Alc HPV+ } \\
\text { (mean\%) }\end{array}$ & $\begin{array}{l}\text { Alc HPV- } \\
\text { (mean\%) }\end{array}$ \\
\hline All studies & 55 & 8084 & 3640 & 4444 & 1879 & 2894 & $52.60 \%$ & $62.70 \%$ \\
\hline OPSCC & 32 & 4884 & 2772 & 2112 & 1310 & 1273 & $43.74 \%$ & $59.26 \%$ \\
\hline oscc & 7 & 671 & 234 & 437 & 150 & 238 & $62.34 \%$ & $58.29 \%$ \\
\hline \multicolumn{9}{|l|}{ Smoking } \\
\hline & $\begin{array}{l}\text { Number } \\
\text { of studies }\end{array}$ & $\begin{array}{l}\text { Number } \\
\text { of patients }\end{array}$ & $\begin{array}{c}\text { Patients } \\
\text { HPV+ }\end{array}$ & $\begin{array}{l}\text { Patients } \\
\text { HPV- }\end{array}$ & $\begin{array}{c}\text { Tobacco } \\
\text { HPV+ }\end{array}$ & $\begin{array}{c}\text { Tobacco } \\
\text { HPV- }\end{array}$ & $\begin{array}{c}\text { Tobacco } \\
\text { HPV+ } \\
\text { (mean\%) }\end{array}$ & $\begin{array}{c}\text { Tobacco } \\
\text { HPV- } \\
\text { (mean\%) }\end{array}$ \\
\hline All studies & 74 & 11029 & 5218 & 5811 & 3168 & 4533 & $61.84 \%$ & $76.65 \%$ \\
\hline OPSCC & 45 & 7445 & 4205 & 3240 & 2469 & 2538 & $57.87 \%$ & $78.65 \%$ \\
\hline oscc & 8 & 779 & 245 & 534 & 167 & 317 & $62.03 \%$ & $60.88 \%$ \\
\hline \multicolumn{9}{|l|}{ Gender } \\
\hline & $\begin{array}{l}\text { Number } \\
\text { of studies }\end{array}$ & $\begin{array}{l}\text { Number } \\
\text { of patients }\end{array}$ & $\begin{array}{l}\text { Patients } \\
\text { HPV+ }_{+}\end{array}$ & $\begin{array}{l}\text { Patients } \\
\text { HPV- }\end{array}$ & $\begin{array}{c}\text { Female } \\
\text { HPV+ } \\
\text { (mean\%) }\end{array}$ & $\begin{array}{c}\text { Female } \\
\text { HPV- } \\
\text { (mean\%) }\end{array}$ & $\begin{array}{c}\text { Male } \\
\text { HPV+ } \\
\text { (mean\%) }\end{array}$ & $\begin{array}{c}\text { Male } \\
\text { HPV- } \\
\text { (mean\%) }\end{array}$ \\
\hline All studies & 92 & 14309 & 6309 & 8000 & $\begin{array}{l}1223 / \\
20.24 \%\end{array}$ & $\begin{array}{l}1626 / \\
21.40 \%\end{array}$ & $\begin{array}{l}5075 / \\
79.33 \%\end{array}$ & $\begin{array}{l}6233 / \\
76.43 \%\end{array}$ \\
\hline OPSCC & 58 & 9161 & 4934 & 4227 & $\begin{array}{c}936 / \\
20.33 \%\end{array}$ & $\begin{array}{c}809 / \\
20.62 \%\end{array}$ & $\begin{array}{l}3998 / \\
79.67 \%\end{array}$ & $\begin{array}{l}3342 / \\
77.32 \%\end{array}$ \\
\hline oscc & 10 & 1114 & 343 & 771 & $\begin{array}{c}75 / \\
21.49 \% \\
\end{array}$ & $\begin{array}{c}168 / \\
22.50 \%\end{array}$ & $\begin{array}{c}267 / \\
77.60 \%\end{array}$ & $\begin{array}{r}525 / \\
65.43 \%\end{array}$ \\
\hline \multicolumn{9}{|l|}{ Countries } \\
\hline & & Europe & \multicolumn{2}{|c|}{ North America } & Asia & Australia & \multicolumn{2}{|c|}{ South America } \\
\hline \multicolumn{2}{|c|}{ Number of studies } & 61 & \multicolumn{2}{|c|}{46} & 23 & 7 & \multicolumn{2}{|c|}{2} \\
\hline OPSCC & \multicolumn{2}{|c|}{ Number of studies } & \multicolumn{2}{|c|}{ Number of patients } & \multicolumn{2}{|c|}{ Patients HPV+ } & \multicolumn{2}{|c|}{ Mean incidence rate } \\
\hline \multicolumn{2}{|l|}{ Europe } & 33 & \multicolumn{2}{|c|}{5891} & \multicolumn{2}{|c|}{2686} & \multicolumn{2}{|c|}{$48.08 \%$} \\
\hline \multicolumn{2}{|c|}{ North America } & 28 & 45 & & & 16 & 52. & $7 \%$ \\
\hline Asia & & 14 & 16 & & & 61 & 43. & $4 \%$ \\
\hline
\end{tabular}

Figure 3. Data regarding HPV risk factors (Bischof C: PhD Thesis, in prep). Age: The upper panel summarizes data without detailed age information (only $\mathrm{HPV}^{+}$patients are older/younger, no significant difference), the lower panel of the data summarizes detailed age information. Alcohol: The number of patients who described themselves as regular alcohol consumers. Smoking: The number of patients who described themselves as regular tobacco consumers. Data are presented as the n number of patients and/or the mean percentage. HPV, human papillomavirus; n.s., not significant; TNM, tumor-node-metastasis; OPSCC, oropharyngeal squamous cell carcinoma; OSCC, oral squamous cell carcinoma.

advantages and disadvantages, the most reliable HPV detection method may be a combined approach that establishes both an accurate result and a cost- and time-effective test method; for instance, the high sensitivity method of p16 IHC may be combined with the high specificity method of PCR and a chip system as described previously (153). The current analysis 


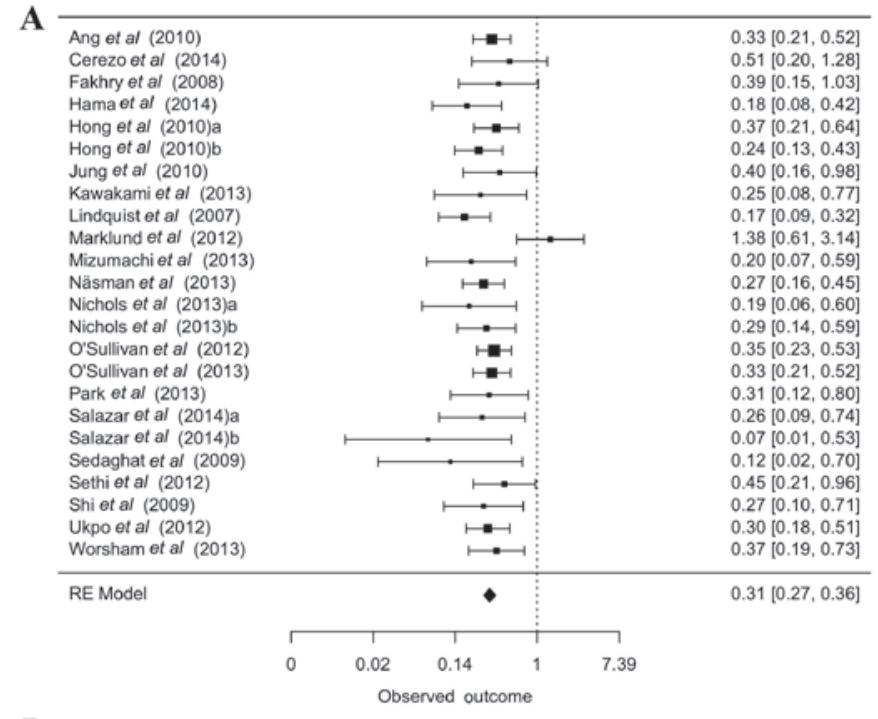

B

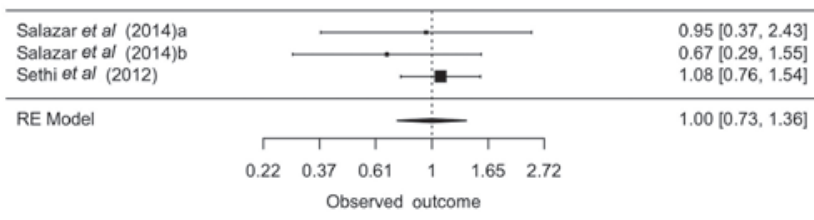

Figure 4. Overall survival regarding HPV positivity, revealed a better outcome for $\mathrm{HPV}^{+}$patients. (A) oropharyngeal tumors and (B) non-oropharyngeal tumors (Bischof C: PhD Thesis, in prep). Pooled adjusted hazard ratio for the overall survival of patients with oropharyngeal squamous cell carcinoma and nonoropharyngeal tumors. The hazard ratios were given in the studies. HPV, human papillomavirus.

compared the results of the various detection methods, but no significant difference was observed. There is an urgent need for uniform standards regarding the HPV test procedure. However, the test method combination described above must first be confirmed as sufficiently accurate. Furthermore, the potential association between viral biological activity/ integration into the host genome/higher viral load and higher survival rate must be clarified.

HPV16 and 18 were the most commonly detected subtypes (11,455 patients in 80 studies on subtype), with this result being consistent with other studies $(150,151)$. Notably, HPV16 was more common in OPSCC than in OSCC (90.55 vs. $69.66 \%)$, and HPV18 was more often detected in OSCC than in OPSCC (26.00 vs. $8.10 \%)$. These observations have previously been described in other studies $(8,150)$.

As mentioned above, the majority of studies observed a survival advantage for $\mathrm{HPV}^{+} \mathrm{HNSCC}$ patients. It needs to be clarified whether all HPV-associated HNSCCs have this prognostic advantage, or whether only certain subsets of HPV-associated HNSCC are affected. Not only the anatomical sub-localizations but also the HPV detection method, the respective HPV subtype, the biological activity and the viral load may limit the extent of potential survival benefit. To avoid insufficient treatment, it needs to be examined more closely whether the survival benefit is independent of the applied treatment. A comparison of the individual studies is difficult, because they differ in certain key points including tumor localization, HPV detection method, the applied treatment and the endpoint of study. In concordance with other studies, a survival advantage of a $69 \%$ lower risk of fatality associated with any cause was observed for patients with HPV-associated OPSCC. For patients with non-oropharyngeal cancers, no survival benefit was identified, although only 3 comparable studies have been conducted. Many studies suggest that not all HPV-associated HNSCC have an improved prognosis, and that the anatomical localization is of prognostic importance $(128,154)$. Also a recent study conducted at the TU Munich found no survival benefit for patients with HPV-associated OSCC (155). Among the above-mentioned five studies (HPV and patient survival) that reported of a worse outcome of patients with HPV-associated carcinomas, mainly patients with non-OPSCC were investigated $(92,96,98,110,126)$. An interesting study by Marklund indicated that perhaps even the localization of 'oropharynx' is too vague, as for neither $\mathrm{p}^{+} 6^{+}$nor $\mathrm{HPV}^{+}$patients with oropharyngeal tumors outside the tonsils and base of the tongue could prognostic benefits be observed (53). Furthermore, in another study, the survival advantage of HPV-associated OPSCC was limited to tumors of the tonsils and base of the tongue (52). Therefore, in future, the description and separation of OPSCC should be more detailed. The reason for HPV-associated cancers having an improved long-term prognosis is still not wholly clear, although several theories have been proposed. The favorable prognosis may be based on the fact that HPV-associated carcinomas have markedly fewer genetic alterations compared with carcinomas induced through noxious agents (44), and thus, an increased sensitivity to DNA-damaging processes exists (156). This observation is also in accordance with the fact that, among patients with HPV-associated cancers, fewer smokers are observed; as the probability of genetic alterations rises with each additional pack year (13). Additionally, this hypothesis is supported by the finding that $\mathrm{HPV}^{+}$tumors with TP53 mutations have not been associated with an improved prognosis $(48,157)$. No conclusion can be made as to whether the improved prognosis for surgically treated patients is invalid because of the small number of cases. Just as TP53 mutations can be observed less frequently in HPV-associated carcinomas (158), other relationships with specific biomarkers have been discussed, for example, the lower expression of epidermal growth factor receptor and a rarer amplification at 11q13 (159). Furthermore, combined effects of the immune response to the virus and the tumor may be responsible; specific T-cells against HPV16 E7 protein have been detected, but their role remains unclear (160). The fact that patients with HPV-associated HNSCC rarely develop secondary tumors may contribute to improved survival rates (161), although it should be noted that patients affected by HPV-associated cancers are mostly younger $(13,88,139,162-165)$ and are less often tobacco and alcohol consumers $(87,116)$. Certain studies claim that tobacco consumption is of prognostic significance in $\mathrm{HPV}^{+}$and $\mathrm{HPV}^{-}$patients $(13,32,33,54)$. However, some other studies refute this thesis, claiming the improved prognosis observed in $\mathrm{HPV}^{+}$patients is independent of their tobacco consumption (26). Regarding comorbidities, for patients with $\mathrm{HPV}^{+}$OPSCC and, in general, HNSCC with lower comorbidities, a significantly improved long-term survival has been observed (104). In contrast, for patients with HPV-associated OPSCC/HNSCC with higher comorbidities, no prognostic benefit has been recognized (104). This suggests that the 
health status of the patients should be considered (104). With respect to the detection methods, as explained above, the examination of HPV status with a combined method utilizing p16 IHC, PCR and chip analysis may be advantageous (153). However, the molecular mechanisms that underlie the presumed survival advantage have not yet been sufficiently studied. Thus, no definitive recommendations can be made for HPV detection, and further studies are still needed. Additional tests, including for TP53 mutations, amplification at 11q13, and E6 and E7 PCR may be helpful (154). In addition to the previously described factors that may influence the prognostic relevance of HPV-associated HNSCC, one important question is whether the supposed improved outcome is independent of the treatment method employed. An improved response to chemotherapy and radiotherapy has been discussed, but even for this there is disagreement; $\mathrm{p} 16^{+}$patients often underwent a more aggressive adjuvant therapy, because of their more frequent lymph node involvement and lower rate of comorbidities (14). This raises the question as to whether the prognostic benefits are attributable to the more intense treatment and not to the less aggressive tumors (14). Baumeister et al (14) also indicated that the most common causes of mortality in patients with HPV-associated carcinomas were distant metastases and the relatively late tumor onset; thus a 10-year monitoring period was suggested to be advantageous.

Regarding published studies on HPV infection in HNSCC, it should be noted that the detection methods and study cohorts may provide bias. Furthermore, the role of HPV infection in OSCC is of minor relevance, and only a minority of cases are $\mathrm{HPV}^{+}$. In OPSCC, and particularly in cancers of the tonsils and base of the tongue, HPV infection and positivity for the surrogate marker p16 may be of high relevance for survival. Therefore, p16-positivity is included in the recent World Health organization TNM classification for OPSCC. In the next few years, the predicted rising numbers of vaccination against HPV infection may serve a notable role regarding the incidence of $\mathrm{HPV}^{+}$cancers. For details see also 'Bischof $\mathrm{C}$ : $\mathrm{PhD}$ Thesis, in prep'.

\section{Acknowledgements}

The authors would like to thank Dr Lynne Stecher for providing support and helpful contributions to this manuscript.

\section{Funding}

No funding was received.

\section{Availability of data and materials}

The datasets analyzed during the current study are available from the corresponding author on reasonable request.

\section{Authors' contributions}

$\mathrm{CG}, \mathrm{CB}, \mathrm{LS}, \mathrm{KDW}$ and AK designed the study. CG, CB, LS, KDW and AK conducted the study. $\mathrm{CG}$ and $\mathrm{CB}$ collected the data. $C G, \mathrm{LS}$ and $\mathrm{CB}$ analyzed the data. $\mathrm{CG}$ and $\mathrm{CB}$ interpreted the data. $\mathrm{CG}, \mathrm{CB}, \mathrm{LS}, \mathrm{KDW}$ and $\mathrm{AK}$ drafted the manuscript. $\mathrm{CG}, \mathrm{CB}, \mathrm{LS}, \mathrm{KDW}$ and AK wrote the manuscript. CG, CB, LS,
KDW and AK approved the final version of the manuscript. $C G$, $\mathrm{CB}, \mathrm{LS}, \mathrm{KDW}$ and AK take responsibility for the integrity of the data analysis.

\section{Ethics approval and consent to participate}

Not applicable.

\section{Patient consent for publication}

Not applicable.

\section{Competing interests}

The authors declare that they have no competing interests.

\section{References}

1. Ferlay J, Shin HR, Bray F, Forman D, Mathers C and Parkin DM: Estimates of worldwide burden of cancer in 2008: GLOBOCAN 2008. International journal of cancer. J Int Cancer 127: 2893-2917, 2010.

2. Kaatsch P, Spix C, Katalinic A, Hentschel S, Luttmann S and Stegmaier C: Cancer in Germany 2011/2012. Robert Koch Institute and the Society of Epidemiological Cancer Registries in Germany. Robert-Koch-Institut, Berlin, 2015 (In German).

3. Licitra L, Zigon G, Gatta G, Sanchez MJ and Berrino F: Human papillomavirus in HNSCC: A European epidemiologic perspective. Hematol Oncol Clin North Am 22: 1143-1153, vii-viii, 2008.

4. Chaturvedi AK, Engels EA, Anderson WF and Gillison ML: Incidence trends for human papillomavirus-related and -unrelated oral squamous cell carcinomas in the United States. J Clin Oncol 26: 612-619, 2008.

5. Syrjänen KJ, Pyrhönen S, Syrjänen SM and Lamberg MA: Immunohistochemical demonstration of human papilloma virus (HPV) antigens in oral squamous cell lesions. Br J Oral Surg 21: 147-153, 1983.

6. World Health Organization; International Agency for Research on Cancer: Human Papillomaviruses. IARc Monographs on the Evaluation of Carcinogenic Risks to Humans. Vol 90. IARC, Lyon, pp1-636, 2007.

7. Chaturvedi AK, Engels EA, Pfeiffer RM, Hernandez BY, Xiao W Kim E, Jiang B, Goodman MT, Sibug-Saber M, Cozen W, et al: Human papillomavirus and rising oropharyngeal cancer incidence in the United States. J Clin Oncol 29: 4294-4301, 2011.

8. Mehanna H, Beech T, Nicholson T, El-Hariry I, McConkey C, Paleri V and Roberts S: Prevalence of human papillomavirus in oropharyngeal and nonoropharyngeal head and neck cancer-systematic review and meta-analysis of trends by time and region. Head Neck 35: 747-755, 2013.

9. Stein AP, Saha S, Yu M, Kimple RJ and Lambert PF: Prevalence of human papillomavirus in oropharyngeal squamous cell carcinoma in the United States across time. Chem Res Toxicol 27: 462-469, 2014

10. Liberati A, Altman DG, Tetzlaff J, Mulrow C, Gøtzsche PC, Ioannidis JP, Clarke M, Devereaux PJ, Kleijnen J and Moher D: The PRISMA statement for reporting systematic reviews and meta-analyses of studies that evaluate health care interventions: Explanation and elaboration. PLoS Med 6: e1000100, 2009.

11. Moher D1, Liberati A, Tetzlaff J and Altman DG; PRISMA Group: Preferred reporting items for systematic reviews and meta-analyses: the PRISMA statement. Ann Intern Med 151: 264-269, 2009.

12. Al-Swiahb JN, Huang CC, Fang FM, Chuang HC, Huang HY, Luo SD, Chen $\mathrm{CH}$, Chen CM and Chien CY: Prognostic impact of p16, p53, epidermal growth factor receptor, and human papillomavirus in oropharyngeal cancer in a betel nut-chewing area. Arch Otolaryngol Head Neck Surg 136: 502-508, 2010.

13. Ang KK, Harris J, Wheeler R, Weber R, Rosenthal DI, Nguyen-Tân PF, Westra WH, Chung CH, Jordan RC, Lu C, et al: Human papillomavirus and survival of patients with oropharyngeal cancer. N Engl J Med 363: 24-35, 2010.

14. Baumeister P, Reiter M, Welz C, Becker S, Betz C and Harréus U: Surgically treated oropharyngeal cancer: Risk factors and tumor characteristics. J Cancer Res Clin Oncol 140: 1011-1019, 2014. 
15. Bledsoe TJ, Noble AR, Hunter GK, Rybicki LA, Hoschar A Chute DJ, Saxton JP, Greskovich JF, Adelstein DJ and Koyfman SA: Oropharyngeal squamous cell carcinoma with known human papillomavirus status treated with definitive chemoradiotherapy: Patterns of failure and toxicity outcomes. Radiat Oncol 8: 174, 2013.

16. Bossi P, Orlandi E, Miceli R, Perrone F, Guzzo M, Mariani L, Granata R, Locati L, Fallai C, Cortelazzi B, Pilotti S, et al: Treatment-related outcome of oropharyngeal cancer patients differentiated by HPV dictated risk profile: a tertiary cancer centre series analysis. Ann Oncol 25: 694-699, 2014.

17. Broglie MA, Soltermann A, Rohrbach D, Haile SR, Pawlita M, Studer G, Huber GF, Moch H and Stoeckli SJ: Impact of p16, p53, smoking, and alcohol on survival in patients with oropharyngeal squamous cell carcinoma treated with primary intensity-modulated chemoradiation. Head Neck 35: 1698-1706, 2013.

18. Bussu F, Sali M, Gallus R, Petrone G, Zannoni GF, Autorino R, Dinapoli N, Santangelo R, Vellone VG, Graziani C, et al: Human papillomavirus (HPV) infection in squamous cell carcinomas arising from the oropharynx: Detection of HPV DNA and p16 immunohistochemistry as diagnostic and prognostic indicators-a pilot study. Int J Radiat Oncol Biol Phys 89: 1115-1120, 2014

19. Cerezo L, López C, de la Torre A, Suárez D, Hervás A, Ruiz A, Ballestín C, Martín M and Sandoval P: Incidence of human papillomavirus-related oropharyngeal cancer and outcomes after chemoradiation in a population of heavy smokers. Head Neck 36 782-786, 2014

20. Charfi L, Jouffroy T, de Cremoux P, Le Peltier N, Thioux M, Fréneaux P, Point D, Girod A, Rodriguez J and Sastre-Garau X: Two types of squamous cell carcinoma of the palatine tonsil characterized by distinct etiology, molecular features and outcome. Cancer Lett 260: 72-78, 2008.

21. Chernock RD, Zhang Q, El-Mofty SK, Thorstad WL and Lewis JS Jr: Human papillomavirus-related squamous cell carcinoma of the oropharynx: A comparative study in whites and African Americans. Arch Otolaryngol Head Neck Surg 137: 163-169, 2011.

22. Chien CY, Su CY, Fang FM, Huang HY, Chuang HC, Chen CM and Huang CC: Lower prevalence but favorable survival for human papillomavirus-related squamous cell carcinoma of tonsil in Taiwan. Oral Oncol 44: 174-179, 2008.

23. Cohen MA, Weinstein GS, O'Malley BW Jr, Feldman M and Quon H: Transoral robotic surgery and human papillomavirus status: Oncologic results. Head Neck 33: 573-580, 2011.

24. D'Souza G, Kreimer AR, Viscidi R, Pawlita M, Fakhry C, Koch WM, Westra WH and Gillison ML: Case-control study of human papillomavirus and oropharyngeal cancer. N Engl J Med 356: 1944-1956, 2007.

25. Ernster JA, Sciotto CG, O'Brien MM, Finch JL, Robinson LJ, Willson $\mathrm{T}$ and Mathews M: Rising incidence of oropharyngeal cancer and the role of oncogenic human papilloma virus Laryngoscope 117: 2115-2128, 2007

26. Evans M, Newcombe R, Fiander A, Powell J, Rolles M, Thavaraj S, Robinson M and Powell N: Human Papillomavirusassociated oropharyngeal cancer: An observational study of diagnosis, prevalence and prognosis in a UK population. BMC Cancer 13: 220, 2013.

27. Fakhry C, Zhang Q, Nguyen-Tan PF, Rosenthal D, El-Naggar A, Garden AS, Soulieres D, Trotti A, Avizonis V, Ridge JA, et al: Human papillomavirus and overall survival after progression of oropharyngeal squamous cell carcinoma. J Clin Oncol 32 3365-3373, 2014

28. Fallai C, Perrone F, Licitra L, Pilotti S, Locati L, Bossi P, Orlandi E, Palazzi M and Olmi P: Oropharyngeal squamous cell carcinoma treated with radiotherapy or radiochemotherapy: Prognostic role of TP53 and HPV status. Int J Radiat Oncol Bio Phys 75: 1053-1059, 2009.

29. Fei J, Hong A, Dobbins TA, Jones D, Lee CS, Loo C, Al-Ghamdi M, Harnett GB, Clark J, O'Brien CJ, et al: Prognostic significance of vascular endothelial growth factor in squamous cell carcinomas of the tonsil in relation to human papillomavirus status and epidermal growth factor receptor. Ann Surg Oncol 16: 2908-2917, 2009

30. Fischer CA, Kampmann M, Zlobec I, Green E, Tornillo L, Lugli A, Wolfensberger M and Terracciano LM: p16 expression in oropharyngeal cancer: its impact on staging and prognosis compared with the conventional clinical staging parameters. Ann Oncol 21: 1961-1966, 2010.
31. Geiger JL, Lazim AF, Walsh FJ, Foote RL, Moore EJ, Okuno SH, Olsen KD, Kasperbauer JL, Price DL, Garces YI, et al: Adjuvant chemoradiation therapy with high-dose versus weekly cisplatin for resected, locally-advanced HPV/p16-positive and negative head and neck squamous cell carcinoma. Oral Oncol 50: 311-318, 2014.

32. Gillison ML, Zhang Q, Jordan R, Xiao W, Westra WH, Trotti A, Spencer S, Harris J, Chung CH and Ang KK: Tobacco smoking and increased risk of death and progression for patients with p16-positive and p16-negative oropharyngeal cancer. J Clin Oncol 30: 2102-2111, 2012.

33. Hafkamp HC, Manni JJ, Haesevoets A, Voogd AC, Schepers M, Bot FJ, Hopman AH, Ramaekers FC and Speel EJ: Marked differences in survival rate between smokers and nonsmokers with HPV 16-associated tonsillar carcinomas. Int J Cancer 122: 2656-2664, 2008.

34. Hama T, Tokumaru Y, Fujii M, Yane K, Okami K, Kato K, Masuda M, Mineta H, Nakashima T, Sugasawa M, et al: Prevalence of human papillomavirus in oropharyngeal cancer: A multicenter study in Japan. Oncology 87: 173-182, 2014.

35. Hannisdal K, Schjølberg A, De Angelis PM, Boysen M and Clausen OP: Human papillomavirus (HPV)-positive tonsillar carcinomas are frequent and have a favourable prognosis in males in Norway. Acta Otolaryngol 130: 293-299, 2010.

36. Hong A, Dobbins T, Lee CS, Jones D, Jackson E, Clark J, Armstrong B, Harnett G, Milross C, O'Brien C and Rose B: Relationships between epidermal growth factor receptor expression and human papillomavirus status as markers of prognosis in oropharyngeal cancer. Eur J Cancer 46: 2088-2096, 2010.

37. Hong AM, Dobbins TA, Lee CS, Jones D, Harnett GB Armstrong BK, Clark JR, Milross CG, Kim J, O'Brien CJ, et al: Human papillomavirus predicts outcome in oropharyngeal cancer in patients treated primarily with surgery or radiation therapy. Br J Cancer 103: 1510-1517, 2010.

38. Huang H, Zhang B, Chen W, Zhou SM, Zhang YX, Gao L, Xu ZG, Qiao YL and Tang PZ: Human papillomavirus infection and prognostic predictors in patients with oropharyngeal squamous cell carcinoma. Asian Pac J Cancer Prev 13: 891-896, 2012.

39. Isayeva T, Xu J, Dai Q, Whitley AC, Bonner J, Nabell L, Spencer S, Carroll W, Jones G, Ragin C, et al: African Americans with oropharyngeal carcinoma have significantly poorer outcomes despite similar rates of human papillomavirus-mediated carcinogenesis. Hum Pathol 45: 310-319, 2014.

40. Joo YH, Cho KJ, Park JO, Nam IC and Kim MS: Factors influencing the outcomes of primary surgery with postoperative radiotherapy for $\mathrm{pN} 2$ oropharyneal squamous cell carcinoma. Oral Oncol 48: 90-94, 2012.

41. Jung AC, Briolat J, Millon R, de Reyniès A, Rickman D, Thomas E, Abecassis J, Clavel C and Wasylyk B: Biological and clinical relevance of transcriptionally active human papillomavirus (HPV) infection in oropharynx squamous cell carcinoma. International journal of cancer. Int J Cancer 126: 1882-1894, 2010

42. Junor E, Kerr G, Oniscu A, Campbell S, Kouzeli I, Gourley C and Cuschieri K: Benefit of chemotherapy as part of treatment for HPV DNA-positive but p16-negative squamous cell carcinoma of the oropharynx. Br J Cancer 106: 358-365, 2012.

43. Kawakami H, Okamoto I, Terao K, Sakai K, Suzuki M, Ueda S, Tanaka K, Kuwata K, Morita Y, Ono K, et al: Human papillomavirus DNA and p16 expression in Japanese patients with oropharyngeal squamous cell carcinoma. Cancer Med 2: 933-941, 2013

44. Klussmann JP, Mooren JJ, Lehnen M, Claessen SM, Stenner M, Huebbers CU, Weissenborn SJ, Wedemeyer I, Preuss SF, Straetmans JM and Manni JJ: Genetic signatures of HPV-related and unrelated oropharyngeal carcinoma and their prognostic implications. Clin Cancer Res 15: 1779-1786, 2009.

45. Kuo KT, Hsiao CH, Lin CH, Kuo LT, Huang SH and Lin MC: The biomarkers of human papillomavirus infection in tonsillar squamous cell carcinoma-molecular basis and predicting favorable outcome. Mod Pathol 21: 376-386, 2008.

46. Lewis JS Jr, Thorstad WL, Chernock RD, Haughey BH, Yip JH, Zhang Q and El-Mofty SK: p16 positive oropharyngeal squamous cell carcinoma:an entity with a favorable prognosis regardless of tumor HPV status. Am J Surg Pathol 34: 1088-1096, 2010.

47. Li W, Thompson CH, O'Brien CJ, McNeil EB, Scolyer RA, Cossart YE, Veness MJ, Walker DM, Morgan GJ and Rose BR: Human papillomavirus positivity predicts favourable outcome for squamous carcinoma of the tonsil. International journal of cancer. Int J Cancer 106: 553-558, 2003. 
48. Licitra L, Perrone F, Bossi P, Suardi S, Mariani L, Artusi R, Oggionni M, Rossini C, Cantù G, Squadrelli M, et al: High-risk human papillomavirus affects prognosis in patients with surgically treated oropharyngeal squamous cell carcinoma. J Clin Oncol 24: 5630-5636, 2006.

49. Lin BM, Wang H, D'Souza G, Zhang Z, Fakhry C, Joseph AW, Drake VE, Sanguineti G, Westra WH and Pai SI: Long-term prognosis and risk factors among patients with HPV-associated oropharyngeal squamous cell carcinoma. Cancer 119: 3462-3471, 2013.

50. Lindquist D, Ahrlund-Richter A, Tarján M, Tot T and DalianisT: Intense CD44 expression is a negative prognostic factor in tonsillar and base of tongue cancer. Anticancer Res 32: 153-161, 2012.

51. Lindquist D, Romanitan M, Hammarstedt L, Näsman A, Dahlstrand H, Lindholm J, Onelöv L, Ramqvist T, Ye W, Munck-Wikland E, et al: Human papillomavirus is a favourable prognostic factor in tonsillar cancer and its oncogenic role is supported by the expression of E6 and E7. Mol Oncol 1: 350-355, 2007.

52. Ljøkjel B, Lybak S, Haave H, Olofsson J, Vintermyr OK and Aarstad HJ: The impact of HPV infection on survival in a geographically defined cohort of oropharynx squamous cell carcinoma (OPSCC) patients in whom surgical treatment has been one main treatment. Acta Otolaryngol 134: 636-645, 2014.

53. Marklund L, Näsman A, Ramqvist T, Dalianis T, MunckWikland E and Hammarstedt L: Prevalence of human papillomavirus and survival in oropharyngeal cancer other than tonsil or base of tongue cancer. Cancer Med 1: 82-88, 2012

54. Maxwell JH, Kumar B, Feng FY, Worden FP, Lee JS, Eisbruch A, Wolf GT, Prince ME, Moyer JS, Teknos TN, Chepeha DB, et al: Tobacco use in human papillomavirus-positive advanced oropharynx cancer patients related to increased risk of distant metastases and tumor recurrence. Clin Cancer Res 16: 1226-1235, 2010.

55. Melkane AE, Auperin A, Saulnier P, Lacroix L, Vielh P, Casiraghi O, Msakni I, Drusch F and Temam S: Human papillomavirus prevalence and prognostic implication in oropharyngea squamous cell carcinomas. Head Neck 36: 257-265, 2014.

56. Mizumachi T, Kano S, Sakashita T, Hatakeyama H, Suzuki S Homma A, Oridate N and Fukuda S: Improved survival of Japanese patients with human papillomavirus-positive oropharyngeal squamous cell carcinoma. Int J Clin Oncol 18: 824-828, 2013.

57. Näsman A, Nordfors C, Grün N, Munck-Wikland E, Ramqvist T, Marklund L, Lindquist D and Dalianis T: Absent/weak CD44 intensity and positive human papillomavirus (HPV) status in oropharyngeal squamous cell carcinoma indicates a very high survival. Cancer Med 2: 507-518, 2013.

58. Nichols AC, Dhaliwal SS, Palma DA, Basmaji J, Chapeskie C, Dowthwaite S, Franklin JH, Fung K, Kwan K, Wehrli B, et al: Does HPV type affect outcome in oropharyngeal cancer? J Otolaryngol Head Neck Surg 42: 9, 2013.

59. Nichols AC, Palma DA, Dhaliwal SS, Tan S, Theuer J, Chow W, Rajakumar C, Um S, Mundi N, Berk S, et al: The epidemic of human papillomavirus and oropharyngeal cancer in a Canadian population. Curr Oncol 20: 212-219, 2013.

60. Nichols AC, Finkelstein DM, Faquin WC, Westra WH, Mroz EA Kneuertz P, Begum S, Michaud WA, Busse PM, Clark JR and Rocco JW: Bcl2 and human papilloma virus 16 as predictors of outcome following concurrent chemoradiation for advanced oropharyngeal cancer. Clin Cancer Res 16: 2138-2146, 2010.

61. O'Sullivan B, Huang SH, Perez-Ordonez B, Massey C, Siu LL, Weinreb I, Hope A, Kim J, Bayley AJ, Cummings B, et al: Outcomes of HPV-related oropharyngeal cancer patients treated by radiotherapy alone using altered fractionation. Radiother Oncol 103: 49-56, 2012.

62. O'Sullivan B, Huang SH, Siu LL, Waldron J, Zhao H, Perez-Ordonez B, Weinreb I, Kim J, Ringash J, Bayley A, et al: Deintensification candidate subgroups in human papillomavirus-related oropharyngeal cancer according to minimal risk of distant metastasis. J Clin Oncol 31: 543-550, 2013.

63. Oguejiofor KK, Hall JS, Mani N, Douglas C, Slevin NJ, Homer J, Hall $G$ and West CM: The prognostic significance of the biomarker p16 in oropharyngeal squamous cell carcinoma. Clin Oncol (R Coll Radiol) 25: 630-638, 2013.

64. Park K, Cho KJ, Lee M, Yoon DH, Kim J, Kim SY, Nam SY, Choi SH, Roh JL, Han MW, et al: p16 immunohistochemistry alone is a better prognosticator in tonsil cancer than human papillomavirus in situ hybridization with or without p16 immunohistochemistry. Acta Otolaryngol 133: 297-304, 2013
65. Park WS, Ryu J, Cho KH, Choi MK, Moon SH, Yun T, ChunBS, Lee GK, Ahn HJ, Lee JH, et al: Human papillomavirus in oropharyngeal squamous cell carcinomas in Korea: Use of G1 cycle markers as new prognosticators. Head Neck 34: 1408-1417, 2012.

66. Posner MR, Lorch JH, Goloubeva O, Tan M, Schumaker LM, Sarlis NJ, Haddad RI and Cullen KJ: Survival and human papillomavirus in oropharynx cancer in TAX 324: a subset analysis from an international phase III trial. Ann Oncol 22: 1071-1077, 2011.

67. Psychogios G, Alexiou C, Agaimy A, Brunner K, Koch M, Mantsopoulos K, Tomppert A and Iro H: Epidemiology and survival of HPV-related tonsillar carcinoma. Cancer Med 3 : 652-659, 2014

68. Psychogios G, Mantsopoulos K, Agaimy A, Koch M, Zenk J, Waldfahrer F and Iro H: Prognostic factors in limited (T1-2, N0-1) oropharyngeal carcinoma treated with surgery \pm adjuvant therapy. Head Neck 35: 1752-1758, 2013.

69. Rahmati R, Dogan S, Pyke O, Palmer F, Awad M, Lee N, Kraus DH, Shah JP, Patel SG and Ganly I: Squamous cell carcinoma of the tonsil managed by conventional surgery and postoperative radiation. Head Neck 37: 800-807, 2014

70. Reimers N, Kasper HU, Weissenborn SJ, Stützer H, Preuss SF, Hoffmann TK, Speel EJ, Dienes HP, Pfister HJ, Guntinas-Lichius $\mathrm{O}$ and Klussmann JP: Combined analysis of HPV-DNA, p16 and EGFR expression to predict prognosis in oropharyngeal cancer. Int J Cancer 120: 1731-1738, 2007.

71. Rietbergen MM, Brakenhoff RH, Bloemena E, Witte BI, Snijders PJ, Heideman DA, Boon D, Koljenovic S, Baatenburg-de Jong RJ and Leemans CR: Human papillomavirus detection and comorbidity: critical issues in selection of patients with oropharyngeal cancer for treatment De-escalation trials. Ann Oncol 24: 2740-2745, 2013

72. Rischin D, Young RJ, Fisher R, Fox SB, Le QT, Peters LJ, Solomon B, Choi J, O'Sullivan B, Kenny LM, et al: Prognostic significance of p16INK4A and human papillomavirus in patients with oropharyngeal cancer treated on TROG 02.02 phase III trial. J Clin Oncol 28: 4142-4148, 2010.

73. Rodrigo JP, Heideman DA, García-Pedrero JM, Fresno MF, Brakenhoff RH, Díaz Molina JP, Snijders PJ and Hermsen MA Time trends in the prevalence of HPV in oropharyngeal squamous cell carcinomas in northern Spain (1990-2009). Int J Cancer 134: 487-492, 2014

74. Schache AG, Liloglou T, Risk JM, Liloglou T, Risk JM, Filia A, Jones TM, Sheard J, Woolgar JA, Helliwell TR, Triantafyllou A, Robinson M, Sloan P, et al: Evaluation of human papilloma virus diagnostic testing in oropharyngeal squamous cell carcinoma: sensitivity, specificity, and prognostic discrimination. Clin Cancer Res 17: 6262-6271, 2011.

75. Sedaghat AR, Zhang Z, Begum S, Palermo R, Best S, Ulmer KM, Levine M, Zinreich E, Messing BP, Gold D, et al: Prognostic significance of human papillomavirus in oropharyngeal squamous cell carcinomas. Laryngoscope 119: 1542-1549, 2009.

76. Semrau R, Duerbaum H, Temming S, Huebbers C, Stenner M, Drebber U, Klussmann JP, Müller RP and Preuss SF: Prognostic impact of human papillomavirus status, survivin, and epidermal growth factor receptor expression on survival in patients treated with radiochemotherapy for very advanced nonresectable oropharyngeal cancer. Head Neck 35: 1339-1344, 2013.

77. Shi W, Kato H, Perez-Ordonez B, Pintilie M, Huang S, Hui A, O'Sullivan B, Waldron J, Cummings B, Kim J, et al: Comparative prognostic value of HPV16 E6 mRNA compared with in situ hybridization for human oropharyngeal squamous carcinoma. J Clin Oncol 27: 6213-6221, 2009.

78. Song JS, Kim MS, Park JW, Lee YS and Kang CS: Expression of human papillomavirus-related proteins and its clinical implication in tonsillar squamous cell carcinoma. Korean J Pathol 46: $177-186,2012$.

79. Song X, Sturgis EM, Huang Z, Li X, Li C, Wei Q and Li G: Potentially functional variants of p14ARF are associated with HPV-positive oropharyngeal cancer patients and survival after definitive chemoradiotherapy. Carcinogenesis 35: 62-68, 2014.

80. Straetmans JM, Olthof N, Mooren JJ, de Jong J, Speel EJ and Kremer B: Human papillomavirus reduces the prognostic value of nodal involvement in tonsillar squamous cell carcinomas. Laryngoscope 119: 1951-1957, 2009.

81. Tural D, Eliçin O, Batur S, Arslan D, Öz B, Serdengeçti S and Uzel Ö: Human papillomavirus is independent prognostic factor on outcome of oropharyngeal squamous cell carcinoma. Tumour Biol 34: 3363-3369, 2013 
82. Ukpo OC, Flanagan JJ, Ma XJ, Luo Y, Thorstad WL and Lewis JS Jr: High-risk human papillomavirus E6/E7 mRNA detection by a novel in situ hybridization assay strongly correlates with p16 expression and patient outcomes in oropharyngea squamous cell carcinoma. Am J Surg Pathol 35: 1343-1350, 2011

83. Ukpo OC, Pritchett CV, Lewis JE, Weaver AL, Smith DI and Moore EJ: Human papillomavirus-associated oropharyngeal squamous cell carcinomas: Primary tumor burden and survival in surgical patients. Ann Otol Rhinol Laryngol 118: 368-373, 2009.

84. Ward MJ, Mellows T, Harris S, Webb A, Patel NN, Cox HJ Piper K, Ottensmeier CH, Thomas GJ and King EV: Staging and treatment of oropharyngeal cancer in the human papillomavirus era. Head Neck 37: 1002-1013, 2015.

85. Ward MJ, Thirdborough SM, Mellows T, Riley C, Harris S, Suchak K, Webb A, Hampton C, Patel NN, Randall CJ, et al Tumour-infiltrating lymphocytes predict for outcome in HPV-positive oropharyngeal cancer. Br J Cancer 110: 489-500, 2014.

86. Weinberger PM, Merkley MA, Khichi SS, Lee JR, Psyrri A, Jackson LL and Dynan WS: Human papillomavirus-active head and neck cancer and ethnic health disparities. Laryngoscope 120: 1531-1537, 2010.

87. Weinberger PM, Yu Z, Haffty BG, Kowalski D, Harigopal M, Brandsma J, Sasaki C, Joe J, Camp RL, Rimm DL, et al: Molecular classification identifies a subset of human papillomavirus-associated oropharyngeal cancers with favorable prognosis. J Clin Oncol 24: 736-747, 2006.

88. Worden FP, Kumar B, Lee JS, Wolf GT, Cordell KG, Taylor JM, Urba SG, Eisbruch A, Teknos TN, Chepeha DB, et al: Chemoselection as a strategy for organ preservation in advanced oropharynx cancer: Response and survival positively associated with HPV16 copy number. J Clin Oncol 26: 3138-3146, 2008.

89. Worsham MJ1, Stephen JK, Chen KM, Mahan M, Schweitzer V, Havard S and Divine G: Improved survival with HPV among African Americans with oropharyngeal cancer. Clin Cancer Res 19: 2486-2492, 2013.

90. Young RJ, Rischin D, Fisher R, McArthur GA, Fox SB, Peters LJ, Corry J, Lim A, Waldeck K and Solomon B: Relationship between epidermal growth factor receptor status, p16(INK4A), and outcome in head and neck squamous cell carcinoma. Cancer Epidemiol Biomarkers Prev 20: 1230-1237, 2011

91. Chen YW, Kao SY and Yang MH: Analysis of p16(INK4A) expression of oral squamous cell carcinomas in Taiwan: Prognostic correlation without relevance to betel quid consumption. J Surg Oncol 106: 149-154, 2012.

92.Duray A, Descamps G, Decaestecker C, Remmelink M, Sirtaine N, Lechien J, Ernoux-Neufcoeur P, Bletard N, Somja J, Depuydt CE, et al: Human papillomavirus DNA strongly correlates with a poorer prognosis in oral cavity carcinoma. Laryngoscope 122: 1558-1565, 2012.

93. Elango KJ, Suresh A, Erode EM, Subhadradevi L, Ravindran HK, Iyer SK, Iyer SK and Kuriakose MA: Role of human papilloma virus in oral tongue squamous cell carcinoma. Asian Pac J Cancer Prev 12: 889-896, 2011

94. Gröbe A, Hanken H, Kluwe L, Schöllchen M, Tribius S, Pohlenz P, Clauditz T, Grob T, Simon R, Sauter G, Heiland M and Blessmann M: Immunohistochemical analysis of p16 expression, HPV infection and its prognostic utility in oral squamous cell carcinoma. J Oral Pathol Med 42: 676-681, 2013.

95. Huang SF, Li HF, Liao CT, Wang HM, Chen IH, Chang JT, Chen YJ and Cheng AJ: Association of HPV infections with second primary tumors in early-staged oral cavity cancer. Oral Dis 18: 809-815, 2012.

96. Kozomara R, Jović N, Magić Z, Branković-Magić M and Minić V: p53 mutations and human papillomavirus infection in oral squamous cell carcinomas: correlation with overal survival. J Craniomaxillofac Surg 33: 342-348, 2005.

97. Kruger M, Pabst AM, Walter C, Sagheb K, Günther C, Blatt S, Weise K, Al-Nawas B and Ziebart T: The prevalence of human papilloma virus (HPV) infections in oral squamous cell carcinomas: A retrospective analysis of 88 patients and literature overview. J Craniomaxillofac Surg 42: 1506-1514, 2014.

98. Lee LA, Huang CG, Liao CT, Lee LY, Hsueh C, Chen TC, Lin CY, Fan KH, Wang HM, Huang SF, et al: Human papillomavirus-16 infection in advanced oral cavity cancer patients is related to an increased risk of distant metastases and poor survival. PLoS One 7: e40767, 2012.

99. Lee LA, Huang CG, Tsao KC, Liao CT, Kang CJ, Chang KP, Huang SF, Chen IH, Fang TJ, Li HY, Yang SL, et al: Increasing rates of low-risk human papillomavirus infections in patients with oral cavity squamous cell carcinoma: association with clinical outcomes. J Clin Virol 57: 331-337, 2013.
100. Na, II, Kang HJ, Cho SY, Koh JS, Lee JK, Lee BC, Lee GH, Lee YS, Yoo HJ, Ryoo BY, Yang SH and Shim YS: EGFR mutations and human papillomavirus in squamous cell carcinoma of tongue and tonsil. Eur J Cancer 43: 520-526, 2007.

101. Reuschenbach M, Kansy K, Garbe K, Vinokurova S, Flechtenmacher C, Toth C, Prigge ES, Thiele OC, Reinert S, Hoffmann J, et al: Lack of evidence of human papillomavirusinduced squamous cell carcinomas of the oral cavity in southern Germany. Oral Oncol 49: 937-942, 2013

102. Sugiyama M, Bhawal UK, Kawamura M, Ishioka Y, Shigeishi H, Higashikawa $\mathrm{K}$ and Kamata N: Human papillomavirus-16 in oral squamous cell carcinoma: Clinical correlates and 5-year survival. Br J Oral Maxillofac Surg 45: 116-122, 2007.

103. Zhao D, Xu QG, Chen XM and Fan MW: Human papillomavirus as an independent predictor in oral squamous cell cancer. Int J Oral Sci 1: 119-125, 2009.

104. Ankola AA, Smith RV, Burk RD, Prystowsky MB, Sarta C and Schlecht NF: Comorbidity, human papillomavirus infection and head and neck cancer survival in an ethnically diverse population. Oral Oncol 49: 911-917, 2013.

105. Annertz K, Rosenquist K, Andersson G, Jacobsson H, Hansson BG and Wennerberg J: High-risk HPV and survival in patients with oral and oropharyngeal squamous cell carcinoma - 5-year follow up of a population-based study. Acta Otolaryngol 134: 843-851, 2014.

106. Badaracco G, Rizzo C, Mafera B, Pichi B, Giannarelli D, Rahimi SS, Vigili MG and Venuti A: Molecular analyses and prognostic relevance of HPV in head and neck tumours. Oncol Rep 17: 931-939, 2007.

107. Báez A, Almodóvar JI, Cantor A, Celestin F, Cruz-Cruz L, Fonseca S, Trinidad-Pinedo J and Vega W: High frequency of HPV16-associated head and neck squamous cell carcinoma in the Puerto Rican population. Head Neck 26: 778-784, 2004.

108. Deng Z, Hasegawa M, Aoki K, Matayoshi S, Kiyuna A, Yamashita Y, Uehara T, Agena S, Maeda H, Xie M, et al: A comprehensive evaluation of human papillomavirus positive status and p16INK4a overexpression as a prognostic biomarker in head and neck squamous cell carcinoma. Int $\mathrm{J}$ Oncol 45: 67-76, 2014.

109. Deng Z, Hasegawa M, Yamashita Y, Matayoshi S, Kiyuna A, Agena S, Uehara T, Maeda $\mathrm{H}$ and Suzuki M: Prognostic value of human papillomavirus and squamous cell carcinoma antigen in head and neck squamous cell carcinoma. Cancer Sci 103: 2127-2134, 2012.

110. Duray A, Descamps G, Decaestecker C, Sirtaine N, Gilles A, Khalifé M, Chantrain G, Depuydt CE, Delvenne P and Saussez S: Human papillomavirus predicts the outcome following concomitant chemoradiotherapy in patients with head and neck squamous cell carcinomas. Oncol Rep 30: 371-376, 2013.

111. Fischer CA, Zlobec I, Green E, Probst S, Storck C, Lugli A, Tornillo L, Wolfensberger $\mathrm{M}$ and Terracciano LM: Is the improved prognosis of p16 positive oropharyngeal squamous cell carcinoma dependent of the treatment modality? Int J Cancer 126: 1256-1262, 2010

112. Gavid M, Pillet S, Pozzetto B, Oriol M, Dumollard JM, Timoshenko AP, Martin C and Prades JM: Human papillomavirus and head and neck squamous cell carcinomas in the South-East of France: Prevalence, viral expression, and prognostic implications. Acta Otolaryngol 133: 538-543, 2013.

113. Hoffmann M, Görögh T, Gottschlich S, Lohrey C, Rittgen W, Ambrosch P, Schwarz E and Kahn T: Human papillomaviruses in head and neck cancer: 8 year-survival-analysis of 73 patients. Cancer Lett 218: 199-206, 2005.

114. Joo YH, Jung CK, Sun DI, Park JO, Cho KJ and Kim MS: High-risk human papillomavirus and cervical lymph node metastasis in patients with oropharyngeal cancer. Head Neck 34 : $10-14,2012$

115. Klozar J, Koslabova E, Kratochvil V, Salakova M and Tachezy R: Nodal status is not a prognostic factor in patients with HPV-positive oral/oropharyngeal tumors. J Surg Oncol 107: 625-633, 2013

116. Klozar J, Kratochvil V, Salakova M, Smahelova J, Vesela E, Hamsikova E, Betka J and Tachez R: HPV status and regional metastasis in the prognosis of oral and oropharyngeal cancer. Eur Arch Otorhinolaryngol 265 (Suppl 1): S75-S82, 2008.

117. Kong CS, Narasimhan B, Cao H, Kwok S, Erickson JP, Koong A, Pourmand $\mathrm{N}$ and Le QT: The relationship between human papillomavirus status and other molecular prognostic markers in head and neck squamous cell carcinomas. Int J Radiat Oncol Biol Phys 74: 553-561, 2009. 
118. Laco J, Nekvindova J, Novakova V, Celakovsky P, Dolezalova H, Tucek L, Vosmikova H, Vosmik M, Neskudlova T, Cermakova E, et al: Biologic importance and prognostic significance of selected clinicopathological parameters in patients with oral and oropharyngeal squamous cell carcinoma, with emphasis on smoking, protein p16(INK4a) expression, and HPV status. Neoplasma 59: 398-408, 2012.

119. Lassen P, Eriksen JG, Krogdahl A, Therkildsen MH, Ulhøi BP, Overgaard M, Specht L, Andersen E, Johansen J, Andersen LJ, et al; Danish Head and Neck Cancer Group (DAHANCA): The influence of HPV-associated p16-expression on accelerated fractionated radiotherapy in head and neck cancer: Evaluation of the randomised DAHANCA 6\&7 trial. Radiother Oncol 100: 49-55, 2011.

120.López RV, Levi JE, Eluf-Neto J, Koifman RJ, Koifman S, Curado MP, Michaluart-Junior P, Figueiredo DL, Saggioro FP, de Carvalho MB, et al: Human papillomavirus (HPV) 16 and the prognosis of head and neck cancer in a geographical region with a low prevalence of HPV infection. Cancer Causes Control 25: 461-471, 2014

121. Lukesova E, Boucek J, Rotnaglova E, Salakova M, Koslabova E, Grega M, Eckschlager T, Rihova B, Prochazka B, Klozar J, et al: High level of Tregs is a positive prognostic marker in patients with HPV-positive oral and oropharyngeal squamous cell carcinomas. BioMed Res Int 2014: 303929, 2014.

122. Rades D, Seibold ND, Gebhard MP, Noack F, Schild SE and Thorns C: Prognostic factors (including HPV status) for irradiation of locally advanced squamous cell carcinoma of the head and neck (SCCHN). Strahlenther Onkol 187: 626-632, 2011.

123. Rautava J, Kuuskoski J, Syrjanen K, Grenman R and Syrjanen S: HPV genotypes and their prognostic significance in head and neck squamous cell carcinomas. J Clin Virol 53: 116-120, 2012.

124. Ritchie JM, Smith EM, Summersgill KF, Hoffman HT, Wang D, Klussmann JP, Turek LP and Haugen TH: Human papillomavirus infection as a prognostic factor in carcinomas of the oral cavity and oropharynx. Int J Cancer 104: 336-344, 2003.

125.Rittà M, De Andrea M, Mondini M, Mazibrada J, Giordano C, Pecorari G, Garzaro M, Landolfo V, Schena M, Chiusa L, et al: Cell cycle and viral and immunologic profiles of head and neck squamous cell carcinoma as predictable variables of tumor progression. Head Neck 31: 318-327, 2009.

126. Rosenquist K, Wennerberg J, Annertz K, Schildt EB, Hansson BG, Bladström A and Andersson G: Recurrence in patients with oral and oropharyngeal squamous cell carcinoma: Human papillomavirus and other risk factors. Acta Otolaryngol 127: 980-987, 2007.

127. Salazar CR, Anayannis N, Smith RV, Wang Y, Haigentz M Jr, Garg M, Schiff BA, Kawachi N, Elman J, Belbin TJ, Prystowsky MB, Burk RD and Schlecht NF: Combined P16 and human papillomavirus testing predicts head and neck cancer survival. Int J Cancer 135: 2404-2412, 2014.

128. Salazar CR, Smith RV, Garg MK, Haigentz M Jr, Schiff BA, Kawachi N, Anayannis N, Belbin TJ, Prystowsky MB, Burk RD, et al: Human papillomavirus-associated head and neck squamous cell carcinoma survival: A comparison by tumor site and initial treatment. Head Neck Pathol 8: 77-87, 2014

129. Settle K, Posner MR, Schumaker LM, Tan M, Suntharalingam M, Goloubeva O, Strome SE, Haddad RI, Patel SS, Cambell EV III, et al: Racial survival disparity in head and neck cancer results from low prevalence of human papillomavirus infection in black oropharyngeal cancer patients. Cancer Prev Res (Phila) 2: 776-781, 2009.

130.Smith EM, Rubenstein LM, Haugen TH, Pawlita M and Turek LP: Complex etiology underlies risk and survival in head and neck cancer human papillomavirus, tobacco, and alcohol: A case for multifactor disease. J Oncol 2012: 571862, 2012

131. Smith EM, Rubenstein LM, Hoffman H, Haugen TH and Turek LP: Human papillomavirus, p16 and p53 expression associated with survival of head and neck cancer. Infect Agent Cancer 5: 4, 2010.

132. Smith EM, Wang D, Rubenstein LM, Morris WA, Turek LP and Haugen TH: Association between p53 and human papillomavirus in head and neck cancer survival. Cancer Epidemiol Biomarkers Prev 17: 421-427, 2008.

133. Stephen JK, Divine G, Chen KM, Chitale D, Havard S and Worsham MJ: Significance of p16 in Site-specific HPV Positive and HPV Negative Head and Neck Squamous Cell Carcinoma. Cancer Clin Oncol 2: 51-61, 2013.
134. Thibaudeau E, Fortin B, Coutlée F, Nguyen-Tan P, Weng X, Audet ML, Abboud O, Guertin L, Christopoulos A, Tabet J, et al: HPV prevalence and prognostic value in a prospective cohort of 255 patients with locally advanced HNSCC: A single-centre experience. Int J Otolaryngol 2013: 437815, 2013.

135. Alos L, Moyano S, Nadal A, Alobid I, Blanch JL, Ayala E, Lloveras B, Quint W, Cardesa A and Ordi J: Human papillomaviruses are identified in a subgroup of sinonasal squamous cell carcinomas with favorable outcome. Cancer 115: 2701-2709, 2009.

136.Ernoux-Neufcoeur P, Arafa M, Decaestecker C, Duray A, Remmelink M, Leroy X, Herfs M, Somja J, Depuydt CE, Delvenne P, et al: Combined analysis of HPV DNA, p16, p21 and $\mathrm{p} 53$ to predict prognosis in patients with stage IV hypopharyngeal carcinoma. J Cancer Res Clin Oncol 137: 173-181, 2011.

137. Fakhry C, Westra WH, Li S, Cmelak A, Ridge JA, Pinto H, Forastiere A and Gillison ML: Improved survival of patients with human papillomavirus-positive head and neck squamous cell carcinoma in a prospective clinical trial. J Natl Cancer Inst 100: 261-269, 2008.

138. Friedland P, Thomas A, Naran A, Amanuel B, Grieu-Iacopetta F, Carrello A, Harnett G, Meyer C and Phillips M: Human papillomavirus and gene mutations in head and neck squamous carcinomas. ANZ J Surg 82: 362-366, 2012.

139. Heath S, Willis V, Allan K, Purdie K, Harwood C, Shields P, Simcock R, Williams T and Gilbert DC.: Clinically significant human papilloma virus in squamous cell carcinoma of the head and neck in UK practice. Clin Oncol (R Coll Radiol) 24: e18-23, 2012.

140. Joo YH, Lee YS, Cho KJ, Park JO, Nam IC, Kim CS, Kim SY and Kim MS: Characteristics and prognostic implications of high-risk HPV-associated hypopharyngeal cancers. PLoS One 8: e78718, 2013.

141. Lassen P, Eriksen JG, Hamilton-Dutoit S, Tramm T, Alsner J and Overgaard J: Effect of HPV-associated p16INK4A expression on response to radiotherapy and survival in squamous cell carcinoma of the head and neck. J Clin Oncol 27: 1992-1998, 2009.

142. Lau HY, Brar S, Klimowicz AC, Petrillo SK, Hao D, Brockton NT, Kong CS, Lees-Miller SP and Magliocco AM: Prognostic significance of p16 in locally advanced squamous cell carcinoma of the head and neck treated with concurrent cisplatin and radiotherapy. Head Neck 33: 251-256, 2011.

143. Rampias T, Pectasides E, Prasad M, Sasaki C, Gouveris P, Dimou A, Kountourakis P, Perisanidis C, Burtness B, Zaramboukas T, Rimm D, et al: Molecular profile of head and neck squamous cell carcinomas bearing p16 high phenotype. Ann Oncol 24: 2124-2131, 2013.

144. Sethi S, Ali-Fehmi R, Franceschi S, Struijk L, van Doorn LJ, Quint W, Albashiti B, Ibrahim M and Kato I: Characteristics and survival of head and neck cancer by HPV status: a cancer registry-based study. Int J Cancer 131: 1179-1186, 2012.

145. Sivars L, Näsman A, Tertipis N, Vlastos A, Ramqvist T, Dalianis T, Munck-Wikland E and Nordemar S: Human papillomavirus and $\mathrm{p} 53$ expression in cancer of unknown primary in the head and neck region in relation to clinical outcome. Cancer Med 3: 376-384, 2014.

146. Śnietura M, Jaworska M, Pigłowski W, Goraj-Zając A, Woźniak G, and Lange D: High-risk HPV DNA status and p16 (INK4a) expression as prognostic markers in patients with squamous cell cancer of oral cavity and oropharynx. Pol J Pathol 61: 133-139, 2010.

147. Stephen JK, Chen KM, Shah V, Havard S, Lu M, Schweitzer VP, Gardner $\mathrm{G}$ and Worsham MJ: Human papillomavirus outcomes in an access-to-care laryngeal cancer cohort. Otolaryngol Head Neck Surg 146: 730-738, 2012

148. Tribius S, Hoffmann AS, Bastrop S, Görögh T, Haag J, Röcken C, Clauditz T, Grob T, Wilczak W, Tennstedt P, et al: HPV status in patients with head and neck of carcinoma of unknown primary site: HPV, tobacco smoking, and outcome. Oral Oncol 48: $1178-1184,2012$

149. Weiss D, Koopmann M and Rudack C: Prevalence and impact on clinicopathological characteristics of human papillomavirus-16 DNA in cervical lymph node metastases of head and neck squamous cell carcinoma. Head Neck 33: 856-862, 2011.

150. Kreimer AR, Clifford GM, Boyle P and Franceschi S: Human papillomavirus types in head and neck squamous cell carcinomas worldwide: A systematic review. Cancer Epidemiol Biomarkers Prev 14: 467-475, 2005 
151.Dayyani F, Etzel CJ, Liu M, Ho CH, Lippman SM and Tsao AS: Meta-analysis of the impact of human papillomavirus (HPV) on cancer risk and overall survival in head and neck squamous cell carcinomas (HNSCC). Head Neck Oncol 2: 15, 2010.

152.Ng M, Freeman MK, Fleming TD, Robinson M, Dwyer-Lindgren L, Thomson B, Wollum A, Sanman E, Wulf S, Lopez AD, et al: Smoking prevalence and cigarette consumption in 187 countries, 1980-2012. JAMA 311: 183-192, 2014.

153. Adelstein DJ, Ridge JA, Gillison ML, Chaturvedi AK, D'Souza G, Gravitt PE, Westra W, Psyrri A, Kast WM, Koutsky LA, Giuliano A, et al: Head and neck squamous cell cancer and the human papillomavirus: summary of a National Cancer Institute State of the Science Meeting, November 9-10, 2008, Washington, D.C. Head Neck 31: 1393-1422, 2009.

154. Ragin CC and Taioli E: Survival of squamous cell carcinoma of the head and neck in relation to human papillomavirus infection: review and meta-analysis. Int J Cancer 121: 1813-1820, 2007.

155. Götz C, Drecoll E, Straub M, Bissinger O, Wolff KD and Kolk A Impact of HPV infection on oral squamous cell carcinoma. Oncotarget 7: 76704-76712, 2016

156. Butz K, Geisen C, Ullmann A, Spitkovsky D and Hoppe-Seyler F: Cellular responses of HPV-positive cancer cells to genotoxic anti-cancer agents: repression of E6/E7-oncogene expression and induction of apoptosis. International journal of cancer. Journal international du cancer 68: 506-513, 1996.

157. Hafkamp HC, Speel EJ, Haesevoets A, et al: A subset of head and neck squamous cell carcinomas exhibits integration of HPV 16/18 DNA and overexpression of p16INK4A and p53 in the absence of mutations in $\mathrm{p} 53$ exons 5-8. International journal of cancer. Journal international du cancer 107: 394-400, 2003.

158. Gillison ML, Koch WM, Capone RB, Spafford M, Westra WH Wu L, Zahurak ML, Daniel RW, Viglione M, Symer DE, et al: Evidence for a causal association between human papillomavirus and a subset of head and neck cancers. J Natl Cancer Inst 92: 709-720, 2000.
159. Ragin CC, Taioli E, Weissfeld JL, White JS, Rossie KM, Modugno F and Gollin SM: 11q13 amplification status and human papillomavirus in relation to $\mathrm{p} 16$ expression defines two distinct etiologies of head and neck tumours. Br J Cancer 95: 1432-1438, 2006.

160. Hoffmann TK, Arsov C, Schirlau K,Bas M, Friebe-Hoffmann U, Klussmann JP, Scheckenbach K, Balz V, Bier $\mathrm{H}$ and Whiteside TL: T cells specific for HPV16 E7 epitopes in patients with squamous cell carcinoma of the oropharynx. Int J Cancer 118: 1984-1991, 2006.

161. Chaturvedi AK: Epidemiology and clinical aspects of HPV in head and neck cancers. Head Neck Pathol 6 (Suppl 1): S16-S24, 2012.

162. De Petrini M, Rittà M, Schena M, Chiusa L, Campisi $P$, Giordano C, Landolfo V, Pecorari G and Landolfo S: Head and neck squamous cell carcinoma: Role of the human papillomavirus in tumour progression. New Microbiol 29: 25-33, 2006.

163. Kumar B, Cordell KG, Lee JS, Worden FP, Prince ME, Tran HH, Wolf GT, Urba SG, Chepeha DB, Teknos TN, et al: EGFR, p16, HPV Titer, Bcl-xL and p53, sex, and smoking as indicators of response to therapy and survival in oropharyngeal cancer. J Clin Oncol 26: 3128-3137, 2008.

164. Mellin H, Friesland S, Lewensohn R, Dalianis T and Munck-Wikland E: Human papillomavirus (HPV) DNA in tonsillar cancer: clinical correlates, risk of relapse, and survival. International journal of cancer. Int J Cancer 89: 300-304, 2000.

165. Schwartz SR, Yueh B, McDougall JK, Daling JR and Schwartz SM: Human papillomavirus infection and survival in oral squamous cell cancer: a population-based study. Otolaryngology--head and neck surgery : official journal of American Academy of Otolaryngology-. Head Neck Surg 125: $1-9,2001$. International (CC BY-NC-ND 4.0) License. 